\title{
New Equity Performance Following Chapter 11 Emergence
}

Nicholas K. Wold, Colorado College

Judith A. Laux, (E-mail: jlaux@ coloradocollege.edu), Colorado College

\begin{abstract}
This body of research investigates how the performance of exchange-traded common equity from firms in Chapter 11 bankruptcy emergence compares with common stock from non-bankrupt competitors and recently public peers in short and long-term time horizons. Return data are gathered for a sample of sixteen financially restructured companies, each paired with two nondistressed industry competitors and one recently-public peer. Using the Capital Asset Pricing Model as a primary analytical tool, empirical tests show a positive correlation in equity returns among the samples of restructured and non-distressed market competitors and a stock underperformance from the sample of IPO competitors. These results suggest that markets are better at judging the value of post-Chapter 11 companies relative to newly public companies and refute the theory of IPO price momentum.
\end{abstract}

\section{INTRODUCTION}

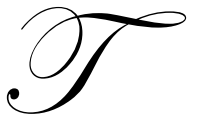

he growth and overall health of an economic system rely on the success of its businesses and their ability to effectively compete with rival firms. One of the most fundamental aspects of a firm's success is its financial state. Specifically, the fiscal stability of a company and its ability to stay profitable are important to sustaining a competitive advantage within an industry and constitute ongoing concerns for management and private and public investors. In recent years, the American automakers' struggle in maintaining market share and the poor operating performance of domestic airlines have created considerable focus on the topic of corporate bankruptcy and the outlook of firms in financial distress. In 2005 alone, over 39,200 American-based firms filed for some type of bankruptcy protection. This volume of corporate bankruptcy filings is a non-trivial issue concerning the American economy and a topic which deserves a closer look.

The purpose of this study is to look at the performance of exchange-traded common equity from firms in Chapter 11 bankruptcy emergence compared to the common stock of non-bankrupt market competitors and recently public peers in a short-term and long-term outlook, using the capital asset pricing model as the primary tool for valuation and analysis. The hypothesis is that the return of common stock issued by firms in Chapter 11 bankruptcy emergence will outperform its market competitors and closely match the performance of its newly public competitors.

The first half of this paper reviews previous empirical research relating to both Chapter 11 bankruptcy and stock performance and summarizes theoretical sources relating to the efficient market hypothesis, behavioral investing trends in capital markets and price momentum in newly-traded equity. The underlying purpose of this section is to provide the reader an adequate background on the historical performance of financially distressed firms and related concepts, creating a foundation of knowledge to help support or refute the current research and results. The second half of this study examines the results of this research, specifically looking at the implications for the performance of financially restructured companies in comparison to their non-distressed peers in both a short-term and long-term time span. 


\section{LITERATURE REVIEW}

\section{Previous Empirical Research}

In an empirical study, written by Russel, Branch, and Torbey [1999], the market performance of 154 financially distressed firms is examined, focusing exclusively on pre-petition equity or stock issued before bankruptcy filing. Using the Black-Scholes pricing model as a primary analysis tool, the study finds that, on average, $70 \%$ of investors lost money in bankrupt equity. Additionally, the study offers irrational investing behavior and market inefficiencies as explanations for why investors decide to allocate capital to bankrupt stock.

In Morse and Shaw [1985], the performance of stock from bankrupt firms from 1973 to 1982 is examined. Using the capital asset pricing model as a tool for analysis, the study finds no significant evidence that investing in bankrupt firms' securities will create abnormal positive returns. There is some indication, however, that the stock price will generally trend upward as companies announce the progression of their reorganization process. The study also notes that, in the case of corporate bankruptcy, secured debt holders are generally the only party in favor of firm liquidation over restructuring due to their high standing on the payout seniority ladder. Unsecured creditors, management, and shareholders, by contrast, generally favor corporate restructuring over liquidation because it maintains the chance that they will receive some kind of payout upon bankruptcy emergence. This source is valuable because of its description and use of the capital asset pricing model. With regard to the current research, this source provides tangible background on how the CAPM can be used to value risky assets and track performance against peers.

In Gilson, Hotchkiss, and Ruback [2000], the market value of a sample of 63 bankrupt firms, taken from 1984 to 1993 , is examined using discounted cash flow analysis. The study finds a large variance in the market value of bankrupt firms, largely attributed to the lack of information available on companies during their restructuring and the difficulty in accurately predicting the future cash flows of distressed firms. This research study is especially useful because it details several ways to value a distressed company and shows how company performance can be tracked without the use of common stock pricing and analysis.

\section{Efficient Market Hypothesis}

The efficient market hypothesis states that in a market with readily available and accessible information, security prices adjust to their intrinsic value. The theory also suggests that current prices of equity reflect all information about that company, its peers, and its industry overall. In Summers [1986], statistical tests are used to evaluate the efficiency of speculative markets. Specifically, the study notes that these tests hold very little power in predicting market valuation of equity based on the present value of a firm's cash flows. The source implies that making speculative investments in equity based on a discounted cash flow analysis of a firm is risky and will not ensure a positive return. The underlying point in the paper is that predicting the returns on a specific piece of equity is difficult and often unreliable based on publicly available information.

In Jarrett and Kyper [2006], analyses are performed on a sample of 62 firms trading on major American stock exchanges over a ten-year period from 1992 to 2002. Specifically, daily closing stock prices are reviewed and tested for any type of time series patterns or predicable trends. The study finds that in a large group of the sampled firms, certain consistent, statistically significant properties are evident where an investor could predict daily stock price patterns, given ample time, patience and mathematical capacity. The study refutes the efficient market theory in that certain predictable and non-random patterns are evident in historical stock price data. The current study tests the theory of efficient markets by comparing the equity returns from formerly bankrupt and newly traded firms with nondistressed market competitors. 


\section{IPO Price Momentum}

The fundamental concept behind IPO stock price momentum is that in a stock's early days of trading on an exchange, investors produce an abnormal positive increase in stock price above the company's intrinsic or fundamental value. In Aggarwal, Prabhala and Puri [2002], a data set of initial public offerings from 1997 and 1998 is analyzed on the basis of institutional allocation. Specifically, the study finds a positive correlation between institutional allocation and one day positive IPO returns. In this case, "institutional allocation" refers to the pattern of underwriters offering under priced equity to institutional fund managers as a way to generate demand and maintain business relationships. The study also supports the idea of "block-building" or investment banks' use of institutional investors' stock price bids and proposed volume purchases to dictate a firm's stock offering price.

In Mauer and Senbet [1992], the authors investigate a sample of 1,002 IPOs during the 1977 to 1984 period, comparing the primary market and secondary market pricing of each initial public offering. Using multiple regression analysis, the study finds a statistically significant price differential between primary and secondary market IPO stock prices. The study attributes the price differential to under pricing in the primary market and asymmetric information among investors in the secondary market. This source underlines inefficiencies across capital markets and supports the theory of positive price momentum in IPOs in their opening days of trading.

\section{DATA}

The question addressed in this study is how the performance of exchange-traded common equity from firms in Chapter 11 bankruptcy emergence compares with common stock from non-bankrupt competitors and recently public peers. The sample of sixteen American-based firms used in this study have all entered and emerged from Chapter 11 bankruptcy with a new issue of public common stock being offered upon emergence. For each formerly distressed sample firm are two non-bankrupt public competitors and a newly-traded peer (IPO) with common stock trading on a U.S. exchange. All companies were chosen using Hoover's Online with competitors being matched by SIC code.

Yahoo! Finance was used to compile historical stock prices, adjusted for stock splits, reverse splits, and dividend payouts, for all companies used in this research. For the sample of formerly-distressed companies and two market competitors, stock price data were gathered during the same time period, with each bankrupt firm's first day of new equity trading serving as "day 1." For the sample of IPO firms, stock price data were collected with "day 1" being the first day of trading for the company's new common stock. Although the IPO competitors' one year of stock price data does not perfectly match up with the financially-restructured firms' stock price data, using the initial public offering date as "day 1" captures any price momentum built into the first days of trading.

\section{METHODOLOGY}

The first measure of equity performance to be used in this study exclusively looks at absolute stock returns among the formerly bankrupt sample of companies against their respective non-bankrupt peers, the S\&P market index, and recently public competitors with one-month, six-month, and one-year time horizons. This method of equity analysis is a simple and straight-forward way of tracking and comparing stock performance.

The second measure of equity performance compares the absolute returns of each formerly bankrupt stock with its own expected rate of return as predicted by the capital asset pricing model. Additionally, the same comparison is made with the two non-bankrupt competitors, and the sample of IPO peers. All comparisons of absolute and expected returns are measured on a one-month, six-month, and one-year basis. This method of equity valuation is useful because it accounts for the beta or perceived risk of each company.

A last measure of equity performance compares the spread or difference between each company's absolute return and its expected rate of return, on one-month, six-month, and full year time horizons. The purpose of this analysis is to see to what extent each company beat or fell short of market expectations. This method of stock analysis 
is useful in that it looks beyond the question of which sample of companies performed the best and instead measures to what degree each company exceeded or fell below projected market expectations.

\section{RESULT AND ANALYSIS}

Table I shows the average and median rates of return for each sample of companies as well as a frequency column for the highest rate of return. The results of the raw stock return comparison show that in both the six-month and full-year results, the returns from the bankrupt sample of companies paired closely with the returns from the sample of market competitors rather than the group of newly public peers. These results suggest that perhaps the public equity from formerly bankrupt and restructured companies trades similar to each company's respective industry rather than being unduly influenced by price momentum, underpricing, or overly positive investing behavior. Additionally, the comparatively low and actual returns of equity from the sample of IPO competitors in a six-month and full-year time horizon further discourage trends of underpricing, positive behavioral investing, and price momentum built into newly-traded common equity.

Table I

High, Average, and Median Rates of Return

\begin{tabular}{|l|c|c|c|}
\hline One-Month Return & Highest Return (n) & Average Return & Median Return \\
\hline Bankrupt Sample (16) & 8 & $5.48 \%$ & $2.63 \%$ \\
\hline Market Competitors & 4 & $2.95 \%$ & $4.10 \%$ \\
\hline IPO Competitor & 4 & $2.68 \%$ & $4.14 \%$ \\
\hline Six-Month Return & & & $10.54 \%$ \\
\hline Bankrupt Sample (16) & 7 & $13.73 \%$ & $5.50 \%$ \\
\hline Market Competitors & 7 & $13.00 \%$ & $-5.42 \%$ \\
\hline IPO Competitor & 2 & $-3.52 \%$ & $31.93 \%$ \\
\hline One-Year Return & & & $23.00 \%$ \\
\hline Bankrupt Sample (16) & 6 & $23.88 \%$ & $-5.93 \%$ \\
\hline Market Competitors & 8 & $22.00 \%$ & $1.29 \%$ \\
\hline IPO Competitor & 2 & & \\
\hline
\end{tabular}

The results from the second measure of equity performance, comparing actual and predicted rates return, showed the bankrupt sample of companies beat their expected rates of return about $60 \%$ of the time in all three time periods (See Table II). Among the sample of IPO competitors, results also did not fluctuate too heavily across time horizons, with about $50 \%$ of the sample beating their predicted rates of return. With regard to the sample of nondistressed market competitors, the number of companies that exceeded expectations grew with each passing time period. At the end of year one, $75 \%$ of the thirty-two firms beat market expectations, a reflection of steady and lowrisk growth. Overall, there seemed to be little connection between the sample of bankrupt firms and IPO competitors in terms of beating expected rates of return for all three time intervals. This lack of correlation fails to support the hypothesis that restructured and newly public companies trend together in an excessively positive direction due to some type of price momentum or irrational investing behavior.

Table III shows the difference between expected and actual rates of return for each bankrupt company, market competitors, and IPO peer. The third measure of equity performance, looking at the spread between expected and actual returns, showed that after one year the sample of restructured firms earned returns that exceed their expected rates of return by 14.75 percentage points with a median positive value of 15.90 . Within the sample of nonbankrupt market competitors, returns averaged 11.35 percentage points above expectations with a median value of 8.00 positive percentage points. Lastly, the IPO stocks averaged a one-year return value that fell short of expectations by 6.54 percentage points with a median of 5.20 points below the expected rate of return. The correlated positive difference between both the restructured and non-bankrupt samples suggests that positive returns are probably not the result of stock underpricing, new equity price momentum, or irrational investing behavior. 
Table II

Actual Vs. Expected Rates of Return

\begin{tabular}{|l|c|c|}
\hline & \multicolumn{2}{|c|}{ Actual Rate of Return } \\
\hline One-Month Return & Greater than Expected Return & Less than Expected Return \\
\hline Bankrupt Sample (16) & $\mathbf{6 2 . 5 0 \%}$ & $37.50 \%$ \\
\hline Market Competitors (32) & $53.13 \%$ & $46.88 \%$ \\
\hline IPO Competitor (16) & $50.00 \%$ & $50.00 \%$ \\
\hline Six-Month Return & & $37.50 \%$ \\
\hline Bankrupt Sample & $62.50 \%$ & $31.25 \%$ \\
\hline Market Competitors & $\mathbf{6 8 . 7 5 \%}$ & $56.25 \%$ \\
\hline IPO Competitor & $43.75 \%$ & $43.75 \%$ \\
\hline One-Year Return & & $25.00 \%$ \\
\hline Bankrupt Sample & $56.25 \%$ & $56.25 \%$ \\
\hline Market Competitors & $\mathbf{7 5 . 0 0 \%}$ & \\
\hline IPO Competitor & $43.75 \%$ & \\
\hline
\end{tabular}

Table III

Actual/Expected Return Difference

\begin{tabular}{|l|c|}
\hline & Actual/Expected Difference \\
\hline One-Month Return & $5.19 \%$ \\
\hline Bankrupt Sample (16) & $1.23 \%$ \\
\hline Market Competitors (32) & $2.04 \%$ \\
\hline IPO Competitor (16) & $15.00 \%$ \\
\hline Six-Month Return & $9.08 \%$ \\
\hline Bankrupt Sample & $-7.57 \%$ \\
\hline Market Competitors & Actual/Expected Difference \\
\hline IPO Competitor & $14.75 \%$ \\
\hline One-Year Return & $11.35 \%$ \\
\hline Bankrupt Sample & $-6.54 \%$ \\
\hline Market Competitors & \\
\hline IPO Competitor & \\
\hline
\end{tabular}

\section{CONCLUSION}

The hypothesis presented in this study states that the return of common stock issued by firms in Chapter 11 bankruptcy emergence will outperform its market competitors and closely match the performance of its newly public competitors. Using the Capital Asset Pricing Model as an analysis tool, empirical tests show a positive correlation in equity returns among the samples of restructured and non-distressed market competitors and a stock underperformance from the sample of IPO competitors. These results suggest that markets are better at judging the value of post-Chapter 11 companies in comparison to newly public companies and refute the theory of IPO price momentum. Additionally, the similar returns from the samples of restructured and non-distressed industry firms support neither the theory of behavioral investing nor the idea of new equity price momentum.

Overall, the financial stability and outlook for any company is a non-trivial issue for investors, management, and the overall strength and health of the economy. This body of research specifically focuses on corporate bankruptcy, investing theory, and capital markets due to their contemporary relevance and importance to any competitive economy. Corporate restructuring, bankruptcy, and insolvency are all inevitable byproducts of freemarket enterprise and business cyclicality. This study offered insight into the often convoluted topic of business finance and helped explain the stock valuation process for any equity, regardless of risk and uncertainty. 


\section{REFERENCES}

1. Aggarwal, Reena, Nagpurnanand R. Prabhala, and Manju Puri. Institutional Allocation of Initial Public Offerings: Empirical Evidence. The Journal of Finance Vol. 57, No. 3 (June 2002): 1421-1442.

2. Business Bankruptcy Statistics: 1994-2006. American Bankruptcy Institute. Accessed September 17, 2006 http://www.abiworld.org/.

3. Gilson, Stuart C. Edith S. Hotchkiss, and Richard S. Ruback. Valuation of Bankrupt Firms. The Review of Financial Studies Vol. 13, No. 1 (spring, 2000): 43-74.

4. Historical Adjusted Stock Prices. Yahoo! Finance. Accessed on Oct. 20, 2006. http://finance.yahoo.com.

5. Hoover's Online Database. Hoover's Company Information. Accessed on Oct. 20, 2006 http://0premium.hoovers.com.tiger.coloradocollege.edu/subscribe/.

6. Jarrett, Jeffrey, and Eric Kyper. Capital Market Efficiency and the Predictability of Daily Returns. Applied Economics (2006): 631-636.

7. Mauer, David C. and Lemma W. Senbet. The Effect of the Secondary Market on the Pricing of Initial Public Offerings: Theory and Evidence. The Journal of Financial and Quantitative Analysis Vol. 27, No. 1 (March 1992): 55-79.

8. Morse, Dale and Wayne Shaw. Investing in Bankrupt Firms. The Journal of Finance Vol. 43, No. 5 (December 1985): 1193-1206.

9. Russel, Phillip S., Ben Branch, Violet Torbey. Market Valuation of Bankrupt Firms: Is There An Anomaly? Quarterly Journal of Business and Economics Vol. 38, No. 2 (spring, 1999): 55-73.

10. Summers, Lawrence H. Does the Market Rationally Reflect Fundamental Values? The Journal of Finance Vol. 41, No. 3 (July 1986): 591-601.

\section{NOTES}

